Gut, 1984, 25, 1331-1339

Leading article

\title{
Early assessment of severity in acute pancreatitis
}

In no other acute abdominal condition is the outcome so unpredictable at the outset. Of any four patients with acute pancreatitis, three will rapidly improve with simple supportive therapy, while the fourth develops one or more serious complications of the disease and stands about a one-in-three chance of dying. ${ }^{-4} \mathrm{~A}$ better understanding of the pathophysiology of pancreatitis, notably the fluid and oxygen requirements, has led to an overall mortality rate of around $10 \%$ in most prospective series. ${ }^{135} \mathrm{~A}$ recent study has shown, however, that a third of fatal cases are first diagnosed at necropsy. When these are included, the overall mortality rate is $20 \% .^{6}$

Separation of patients with good and bad prognoses at the time of admission to hospital is valuable for at least three reasons. First, those with severe pancreatitis need much more vigorous resuscitation and monitoring, including admission to an intensive therapy area, urethral catheterisation and a central venous line. Acute pancreatitis is quite a common emergency and the routine adoption of these measures would be costly. Second, aggresive treatments such as peritoneal lavage, endoscopic papillotomy or urgent pancreatectomy might be justified in patients with a poor outlook, but scarcely so in the majority whose mild attacks quickly abort. Third, general acceptance of the criteria of severity would facilitate international comparisons of prospective studies.

In the present issue a group of surgeons and statisticians report their success in predicting the severity of an attack of acute pancreatitis by means of laboratory tests performed within 48 hours of the patients' arrival at the Glasgow Royal Infirmary. ${ }^{7}$ In evaluating their work we need to define severe pancreatitis, to compare the many methods recommended for its detection and to determine whether the results repay the effort expended. As early operation is one option in treating acute gall stone pancreatitis, we must also consider the identification of this particular group of patients.

\section{Definitions}

As pancreatic tissue is seldom available before death, the diagnosis of acute pancreatitis rests on appropriate clinical features with hyperamylasaemia in at least $80 \%$ of cases and on laparotomy findings in the remainder. ${ }^{138}$ There are several methods of measuring serum amylase, each with its own units; non-pancreatic isoenzymes can be excluded by electrophoresis. ${ }^{9}$ The diagnostic threshold for serum amylase is controversial. It is generally set at a higher level in Britain (1000-2000 IU/1), where gall stones predominate, ${ }^{13510}$ than in the United States 
(200-1000 Somogyi U/dl), where alcoholic disease is commoner. ${ }^{811}$ Besides urinary amylase, the amylase/creatinine clearance ratio can also be measured, ${ }^{12}{ }^{13}$ but its diagnostic value is disputed. ${ }^{914}$ Nor has the serum concentration of any other pancreatic enzyme (trypsin, catalase, lipase, phospholipase) yet been shown to be better than amylase, though trypsin is specific to the pancreas and may remain raised for longer. ${ }^{14} 15$ It is generally agreed that the concentration of serum amylase on admission is of no prognostic value ${ }^{16-19}$ despite occasional reports that high ${ }^{20}$ and low levels ${ }^{21}$ do correlate with severity.

What constitutes a severe attack is also open to different interpretations. Apart from death (which is universally accepted), definitions include the length of stay in an intensive therapy area, ${ }^{20}$ the need for an early operation $^{7}$ and the development of one or more serious complications, ${ }^{3} 10$ some of which - for example, respiratory and renal failure - do not require surgery. Mild attacks are thought to be associated with oedematous pancreatitis and the most severe attacks with 'haemorrhagic suppurative and gangrenous pancreatitis', as originally described by Fitz in $1889 .{ }^{22}$ Whether haemorrhagic and necrotising pancreatitis are separate entities is unclear ${ }^{23}$ Bleeding into the gut or abdominal cavity is rare, but often lethal. ${ }^{24}$ Necrosis is frequently extrapancreatic and leads to abscess formation. Laparotomy findings show that pancreatic haemorrhage and necrosis can be either patchy, or generalised. ${ }^{25} 26$ They probably occur in about $10 \%$ of cases of acute pancreatitis and are associated with a 35-90\% mortality rate. ${ }^{182327} 28$

\section{Single prognostic factors (Table)}

The initial clinical judgment of the severity of an attack of acute pancreatitis is notoriously fallible. Cyanosis, shock, fever, Grey-Turner's sign, tetany and an abdominal mass are all serious signs, but they are often absent in patients who develop serious complications. ${ }^{16} 19$ Severe attacks are only predicted by experienced observers in $34-39 \%$ of patients on admission. ${ }^{10} 29$ This figure does improve to $73 \%$ at 24 hours and to $83 \%$ at

Table Single prognostic factors in acute pancreatitis

\begin{tabular}{|c|c|c|c|}
\hline & & Advantage & Disadvantage \\
\hline 1 & Methaemalbuminaemia & $\begin{array}{l}\text { Specific for haemorrhagic } \\
\text { pancreatitis }\end{array}$ & Insensitive, slow to develop \\
\hline 2 & Fibrinogen & $\begin{array}{l}\text { Rising level correlates with } \\
\text { morbidity }\end{array}$ & $\begin{array}{l}\text { Too slow for early } \\
\text { prognosis }\end{array}$ \\
\hline 3 & Hypoxaemia & $\begin{array}{l}\text { Also indicates a therapeutic } \\
\text { need }\end{array}$ & $\begin{array}{l}\text { Variable baseline, limited } \\
\text { to one aspect of disease }\end{array}$ \\
\hline 4 & Hypocalcaemia & $\begin{array}{l}\text { Reliable if detected on } \\
\text { admission }\end{array}$ & $\begin{array}{l}\text { Insensitive, critical level } \\
\text { disputed }\end{array}$ \\
\hline 5 & Fluid sequestration & $\begin{array}{l}\text { Demonstrates degree of } \\
\text { shock }\end{array}$ & $\begin{array}{l}\text { Crude, needs further } \\
\text { evaluation }\end{array}$ \\
\hline 6 & Complement proteins & $\begin{array}{l}\text { Falling levels of } \mathrm{C}_{3} \text { in } \\
\text { severe attack }\end{array}$ & $\begin{array}{l}\text { Complex technique, } \\
\text { relevance disputed }\end{array}$ \\
\hline 7 & CT scan & $\begin{array}{l}\text { May distinguish } \\
\text { oedematous and } \\
\text { haemorrhagic pancreatitis }\end{array}$ & $\begin{array}{l}\text { Expensive equipment, } \\
\text { further evaluation needed }\end{array}$ \\
\hline 8 & Abdominal paracentesis & $\begin{array}{l}\text { 'Toxic broth' indicates } \\
\text { haemorrhagic disease }\end{array}$ & $\begin{array}{l}\text { Invasive, may not predict } \\
\text { late complications }\end{array}$ \\
\hline
\end{tabular}


48 hours. ${ }^{29}$ There is therefore a need for supplementary indices of severity, although it could be argued that these will be of limited use unless they provide an answer within 48 hours, or nearly complete discrimination thereafter.

The presence of methaemalbumin in the blood has been shown to be highly specific for the haemorrhagic form of pancreatitis. ${ }^{30}$ Methaemalbuminaemia indicates intravascular haemolysis, methaem (haematin) being a breakdown product of haemoglobin which combines with albumin. Two studies have shown that its presence in blood or ascitic fluid carries a 54-66\% chance of death, ${ }^{31}{ }^{32}$ but other reports suggest that it is of little or no value. ${ }^{101417}$ Methodological differences may partly explain the discrepancy, but the big drawback lies in the delay of 72 hours or more before methaemalbumin appears in the circulation. By contrast plasma concentrations of fibrinogen, which also reflect the coagulopathy of acute pancreatitis, seem to be raised on admission ${ }^{33}$ and correlate with other indicators of severity, notably hypoxaemia. ${ }^{13} 3334$

Adult respiratory distress syndrome may result from deposition of fibrin in the lungs and hypoxaemia is a common feature of acute pancreatitis. ${ }^{33} 35$ A $\mathrm{PaO}_{2}$ of $8 \mathrm{kPa}(60 \mathrm{mmHg})$ and below is usually taken to indicate a severe attack, ${ }^{13} 17$ although the actual fall in oxygen saturation will reflect the patient's age and pre-existing respiratory function. In one series half the patients who developed serious complications, or died, had arterial hypoxia $(<8 \mathrm{kPa})$ on admission. ${ }^{3}$ Besides its prognostic value this test offers the additional advantage of revealing unsuspected respiratory insufficiency. ${ }^{33}$

Early hypocalcaemia has long been recognised as a grave prognostic feature in acute pancreatitis. ${ }^{1620}$ The original suggestion that calcium is deposited (as a 'soap') with fatty acids liberated by pancreatic lipase ${ }^{36}$ seems at least as good an explanation as more recent hypotheses that implicate increased concentrations of glucagon and calcitonin, or decreased concentrations of magnesium and parathormone. ${ }^{37-39}$ Whatever the initial cause, subsequent hypocalcaemia reflects the fall in serum albumin. ${ }^{40}$ Measuring serum ionised calcium or simply correcting for albumin content allows an assessment of 'true' calcium concentrations. ${ }^{39} 40$ An uncorrected serum calcium $<2.1 \mathrm{mmol} / 1$ was found within 48 hours in 10 of 18 attacks in one study, but also in 10 of 59 mild attacks. ${ }^{10}$ The more stringent criterion of a corrected serum calcium $<2.0 \mathrm{mmol} / \mathrm{l}$ on admission was more specific (98\%), but less sensitive $(29 \%){ }^{3}$

Continuing fluid sequestration during the first three days was shown to accompany haemorrhagic pancreatitis in one preliminary study. ${ }^{41}$ Declining concentrations of complement proteins, notably $\mathrm{C} 3$, were also reported to correlate with severity ${ }^{42}$ but we have been unable to confirm this. ${ }^{43}$ Although circulating endotoxins can often be detected, their presence is not associated with complications. ${ }^{42}$ Computed tomography scans obtained within 24-48 hours of admission can apparently distinguish between oedematous and haemorrhagic pancreatitis on the basis of phlegmonous changes, ${ }^{44}{ }^{45}$ but here too further evaluation is needed.

Blood stained ascites is found during laparotomy for haemorrhagic pancreatitis. ${ }^{23}$ It was thus a logical though ingenious idea that led McMahon and his colleagues to sample the peritoneal fluid obtained by abdominal paracentesis for prognostic purposes. ${ }^{46}$ After insertion of a 
peritoneal dialysis catheter into the pelvis under local anaesthetic, free fluid was collected before and after peritoneal lavage with one litre of saline. Severe pancreatitis was ajudged by the volume $(>10 \mathrm{ml})$ and dark colour of the free fluid and by the colour of the return fluid after lavage. Using a standard colour chart McMahon was able to predict 13 of 18 severe attacks $(72 \%)$ within a few hours of admission. ${ }^{10}$ Our own experience in some 300 patients has confirmed the ability of peritoneal lavage to identify more than half the cases of severe pancreatitis at this early stage. ${ }^{329}$ The incidence of visceral puncture is less than $1 \%$. The volume of free fluid seems less important than its colour and peritoneal lavage is better at predicting early than late complications of the disease. ${ }^{47}$ One additional dividend of diagnostic peritoneal lavage is that it may show an unexpected cause for the acute abdomen, such as a perforated viscus. ${ }^{348}$

\section{Multiple prognostic factors}

Many clinical and laboratory features had been known to portend death or a complicated illness in acute pancreatitis, ${ }^{19}$ but it was Ranson's achievement to select the best 'package' for early assessment. From a retrospective analysis of 43 early objective findings he selected 11 that correlated with a severe attack; ${ }^{17}$ five could be determined on admission and six within 48 hours. These factors, which are listed in the Table, were based on age, leucocytosis, hyperglycaemia, hepatocellular injury, renal and respiratory insufficiency, hypocalcaemia, a falling haematocrit, metabolic acidosis and fluid sequestration. In a prospective study of 200 patients the 11 factors correctly predicted severity in $92.5 \%$ of cases. ${ }^{49}$ Only one of 162 patients in whom less than three signs were present became seriously ill or died, as opposed to 24 of 38 patients with three or more positive signs. ${ }^{20}$ Later Imrie and colleagues ${ }^{1}$ obtained similar discrimination using an amended list of nine factors, which excluded haematocrit, base deficit and fluid sequestration, but included a low serum albumin (see Table 1, p. 1340).

These multiple criteria remain the yardstick for early assessment of severe acute pancreatitis, but they do have several shortcomings. First, the data base is often incomplete - for example, in $64 \%$ of episodes ${ }^{7}$ - which introduces potential errors into the scoring system. Second, complete data take 48 hours to obtain, by which time clinical assessment is probably as good. ${ }^{10} 29$ Third, both Ranson and Imrie had a high proportion of alcoholic patients $(38-74 \%)$ in the original studies ${ }^{117}$ and their criteria are less satisfactory for gall stone pancreatitis. ${ }^{1050}$ Ranson has responded by dropping one factor (hypoxaemia) and adjusting eight of the other 10 for gall stone patients. ${ }^{51}$ Imrie has responded initially by excluding age and increasing the threshold for transaminase ${ }^{50}$ and now by reintroducing age as a criterion but excluding transaminase altogether. ${ }^{7}$ Age has always seemed a rather weak prognostic index, because the clinical problem is to predict the risk of death whatever the age.

In an attempt to determine the severity of an attack within a few hours of admission, we have used a combination of four factors: hypotension (BP $<100 \mathrm{mmHg}$ ), hypocalcaemia ('corrected' calcium $<2 \mathrm{mmol} / \mathrm{l}$ ), hypoxaemia $\left(\mathrm{PaO}_{2}<8 \mathrm{kPa}\right)$ and the presence of 'toxic broth' $(>10 \mathrm{ml})$ or dark return fluid on abdominal paracentesis. ${ }^{3}$ The presence of any one 
factor constituted a severe attack. These four criteria distinguished severe pancreatitis ( $43 \%$ died) from mild pancreatitis (3\% died), and seven of nine patients fulfilling more than 1 criterion died. There was an overall diagnostic accuracy of $84 \%$.

\section{Detecting the causative gall stone}

The decision to change the management when alerted to the presence of severe pancreatitis may be influenced by the underlying cause. Gall stones are responsible for $50-69 \%$ of attacks of acute pancreatitis in Britain and alcohol for $8-32 \%,{ }^{165253}$ but elsewhere in the world these proportions are reversed. ${ }^{17}$ Can gall stones be detected with reliance early enough in an attack to allow their removal, either urgently to prevent progression of disease, or at least before discharge to abolish the $32-48 \%$ chance of recurrent pancreatitis? ${ }^{11} 505154$

Graham and Wylie used jaundice, right hypochondrial tenderness and Murphy's sign to predict gall stones with $82 \%$ accuracy, ${ }^{55}$ but others have been unable to reproduce their success. ${ }^{56}$ Although serum concentrations of bilirubin, alkaline phosphatase and transaminase are higher in gall stone pancreatitis, ${ }^{58}$ there is considerable overlap with non-biliary pancreatitis; 5659 a specific increase in serum glutamic pyruvic transaminase may be a better discriminant. ${ }^{61}$ Ultrasonography will delineate the calculi in two-thirds of patients, ${ }^{57} 60$ but radionuclide scanning has not fulfilled its early promise. ${ }^{56}$ Invasive cholangiography (percutaneous or endoscopic) may be inappropriate during the initial stages of an attack. It must be concluded that the urgent diagnosis of gall stones in acute pancreatitis is still unsatisfctory, but that most calculi can be demonstrated when symptoms settle, especially if the stools are sieved. ${ }^{11} 5362$

\section{Therapeutic implications}

The strongest justification for urgent attempts to predict haemorrhagic pancreatitis would be if aggressive treatment decreased the high mortality rate of this condition. No drugs are of proven value in established pancreatitis in man; in particular neither glucagon nor aprotinin affect the natural history of the disease. ${ }^{563}$ Peritoneal lavage with hourly cycles of 1-2 litres of warmed dialysate is well tolerated and can produce an apparent clinical improvement, ${ }^{820} 64$ but recent controlled trials have failed to confirm any significant benefit. ${ }^{3465}$ Heroic attempts to remove all or most of the pancreas will undoubtedly salvage some moribund patients 236667 at the expense of an operative mortality of at least one third and a high incidence of septic complications; ${ }^{17} 2668$ average blood loss at operation was 5.6 litres in one report of 18 subtotal pancreatectomies. ${ }^{65}$ Urgent drainage of the pancreatic bed with biliary decompression is of doubtful benefit. ${ }^{17}$

A more promising option would appear to be immediate disimpaction of an ampullary gall stone. Laparotomy findings ${ }^{69} 70$ and retrieval of gall stones from the faeces ${ }^{11} 5362$ leave little doubt that migrating calculi trigger acute pancreatitis, perhaps by damaging the sphincteric mechanism that prevents duodenopancreatic reflux. ${ }^{71}$ There is general agreement that 
cholecystectomy during the same admission is both safe and desirable, ${ }^{50} 7273$ but urgent biliary decompression is another matter altogether. Some surgeons condemn early intervention, ${ }^{50517273}$ yet the high operative mortality rates could reflect either the selection of high-risk cases or an inadequate operation. The work of Acosta and Stone shows that a direct surgical attack on the sphincter within two to three days of admission is not only safe but possibly beneficial, even if the causative gall stone has passed, ${ }^{69} 70$ likewise Ong performed 19 acute sphincteroplasties without any complications. ${ }^{25}$ Endoscopic sphincterotomy within the first few days also appears to be safe. ${ }^{7476}$ It is conceivable that ampullary oedema is the common factor in the pathogenesis of acute pancreatitis and that immediate division of the sphincter might be valuable, irrespective of the cause.

In conclusion many patients who will develop potentially lethal complications of acute pancreatitis can be identified within a few hours of admission to hospital by means of blood gas analysis and inspection of the peritoneal exudate. By 48 hours laboratory investigations should be able to detect $70-90 \%$ of severe attacks, although the precise criteria have still not been established for all types of pancreatitis and clinical assessment can be just as good. Computed tomography scanning is likely to have an expanding role in early detection of a pancreatic phlegmon. Peritoneal aspiration (and lavage) provide the best single test, but also the most invasive; the technique is justified if important differences in treatment depend on the findings.

University Department of Surgery,

R C N WILLIAMSON

Bristol Royal Infimary,

Bristol

\section{References}

1 Imrie CW, Benjamin IS, Ferguson JC et al. A single-centre double-blind trial of Trasylol therapy in primary acute pancreatitis. Br J Surg 1978; 65: 337-41.

2 Satiani S, Stone HH. Predictability of present outcome and future recurrence in acute pancreatitis. Arch Surg 1979; 114: 711-6.

3 Cooper MJ, Williamson RCN, Pollock AV. The role of peritoneal lavage in the prediction and treatment of severe acute pancreatitis. Ann R Coll Surg Engl 1982; 64: 422-7.

4 Mayer AD, McMahon MJ, Corfield AP et al. A randomised trial of peritoneal lavage for the treatment of severe acute pancreatitis. Gastroenterology 1984; 86: 1178.

5 MRC Multicentre Trial. Death from acute pancreatitis. Lancet 1977; 2: 632-5.

6 Corfield AP, Cooper MJ, Williamson RCN. Increased incidence and deaths from acute pancreatitis: disturbing trends. Gut 1984; 25 : 694.

7 Blamey SL, Imrie CW, O'Neill J, Gilmour WH, Carter DC. Prognostic factors in acute pancreatitis. Gut 1984; 25: 1340-6.

8 Ranson JHC, Spencer FC. The role or peritoneal lavage in severe acute pancreatitis. Ann Surg 1978; 187: 565-75.

9 Weaver DW, Bouwman DL, Walt AJ, Clink D, Resto A, Stephany J. A correlation between clinical pancreatitis and izoenzyme patterns of amylase. Surgery 1982; 92: 576-80.

10 McMahon MJ, Playforth MJ, Pickford IR. A comparative study of methods for the prediction of severity of attacks of acute pancreatitis. Br J Surg 1980; 67: 22-5.

11 Kelly TR. Gallstone pancreatitis: the timing of surgery. Surgery 1980; 88: 345-50.

12 Warshaw AL, Fuller AF Jr. Specificity of increased renal clearance of amylase in diagnosis of acute pancreatitis. $N$ Engl J Med 1975; 292: 325-8. 
13 Murray WR, Mackay $\mathrm{C}$. The amylase creatinine clearance ratio in acute pancreatitis. $\mathrm{Br}$ Surg 1977; 64: 189-91.

14 Berry AR, Taylor TV, Davies GC. Diagnostic tests and prognostic indicators in acute pancreatitis. J R Coll Surg Edinb 1982; 27: 345-52.

15 Elias E, Redshaw M, Wood T. Diagnostic importance of changes in circulating concentrations of immunoreactive trypsin. Lancet 1977; 2: 66-8.

16 Trapnell JE. Natural history and prognosis of acute pancreatitis. Ann R Coll Surg Engl 1966; 38: 265-87.

17 Ranson JHC, Rifkind KM, Roses DF, Fink SD, Eng K, Spencer FC. Prognostic signs and the role of operative management in acute pancreatitis. Surg Gynecol Obstet 1974; 139: 69-81.

18 Glazer G. Haemorrhagic and necrotizing pancreatitis. Br J Surg 1975; 62: 169-76.

19 Jacobs ML, Daggett WM, Civetta JM et al. Acute pancreatitis: analysis of factors influencing survival. Ann Surg 1977; 185: 43-51.

20 Ranson JHC, Rifkind KM, Turner JW. Prognostic signs ans nonoperative peritoneal lavage in acute pancreatitis. Surg Gynecol Obstet 1976; 143: 209-19.

21 Adams JT, Libertino JA, Schwartz SI. Significance of an elevated serum amylase. Surgery 1968; 63: 877-84.

22 Fitz RH. Acute pancreatitis. A consideration of pancreatic hemorrhage, hemorrhagic, suppurative, and gangrenous pancreatitis, and of disseminated fat-necrosis. Boston Med Surg J 1889; 120: $181-7$.

23 Frey CF. Hemorrhagic pancreatitis. Am J Surg 1979; 137: 616-23.

24 Stroud WH, Cullom JW, Anderson MC. Hemorrhagic complications of severe pancreatitis. Surgery 1981; 90: 657-65.

25 Ong GB, Lam KH, Lam SK, Lim TK, Wong J. Acute pancreatitis in Hong Kong. Br J Surg 1979; 66: 398-403.

26 Kivilaasko E, Fraki O, Nikki P. Resection of the pancreas for acute fulminant pancreatitis. Surg Gynecol Obstet 1981; 152: 493-8.

27 Lawson DW. Daggett WM, Civetta JM, Corry RJ, Bartlett MK. Surgical treatment of acute necrotizing pancreatitis. Ann Surg 1970; 172: 605-17.

28 Warshaw AL, Imbembo AL, Civetta JM, Daggett WM. Surgical intervention in acute necrotizing pancreatitis. Am J Surg 1974; 127: 484-91.

29 Corfield AP, Cooper MJ, Williamson RCN et al. Prospective assessment of prognostic indicators in acute pancreatitis. Br J Surg 1984. (In press).

30 Winstone NE. Methaemalbumin in acute pancreatitis. Br J Surg 1965; 52: 804-8.

31 Geokas MC, Rinderknecht H, Walberg CB, Weissman R. Methaemalbumin in the diagnosis of acute hemorrhagic pancreatitis. Ann Intern Med 1974; 81: 483-6.

32 Lankisch PG, Koop H, Otto J, Oberdieck U. Evaluation of methaemalbumin in acute pancreatitis. Scand J Gastroenterol 1978; 13: 975-8.

33 Berry AR, Taylor TV, Davies GC. Pulmonary function and fibrinogen metabolism in acute pancreatitis. Br J Surg 1981; 68: 870-3.

34 Ranson JHC, Lackner H, Berman IR, Schinella R. The relationship of coagulation factors to clinical complications of acute pancreatitis. Surgery 1977; 81: 502-11.

35 Murphy D, Pack AI, Imrie CW. The mechanism of arterial hypoxia occurring in acute pancreatitis. $Q J$ Med 1980; 194: 151-63.

36 Edmondson HA, Berne CJ. Calcium changes in acute pancreatic necrosis. Surg Gynecol Obstet 1944; 79: 240-4.

37 Condon JR, Ives D, Knight MJ, Day J. The aetiology of hypocalcaemia in acute pancreatitis. Br J Surg 1975; 62: 115-8.

38 McMahon MJ, Woodhead JS, Hayward RD. The nature of hypocalcaemia in acute pancreatitis. Br J Surg 1978; 65: 216-8.

39 Croton RS, Warren RA, Stott A, Roberts NB. Ionized calcium in acute pancreatitis and its relationships with total calcium and serum lipase. Br J Surg 1981; 68: 241-4.

40 Allam BF, Imrie CW. Serum ionized calcium in acute pancreatitis. Br J Surg 1977; 64: 665-8.

41 Overy RD, Evans M, Pollock AV. Fluid sequestration: an accurate index of severity in acute pancreatitis. Br J Surg 1980; 67: 817.

42 Foulis AK, Murray WR, Galloway D et al. Endotoxaemia and complement activation in acute pancreatitis in man. Gut 1982; 23: 656-61.

43 Whicher JT, Barnes MP, Brown A et al. Complement activation and complement control proteins in acute pancreatitis. Gut 1982; 23: 944-50.

44 Dammann HG, Grabbe E, Runge M. Computed tomography and acute pancreatitis. 
Lancet 1980; 2: 860.

45 Hill MC, Barkin J, Isikoff MB, Silverstein W, Kalser M. Acute pancreatitis: clinical vs. CT findings. AJR 1982; 139: 263-9.

46 Pickford IR, Blackett RJ, McMahon MJ. Early assessment of severity of acute pancreatitis using peritoneal lavage. $\mathrm{Br}$ Med J 1977; 2: 1377-9.

47 Imrie CW, McMahon MJ. Commentary on Cooper MJ, Williamson RCN, Pollock AV, The role of peritoneal lavage in the prediction and treatment of severe acute pancreatitis. Ann R Coll Surg Engl 1982; 64: 425-7.

48 Bradley JA, Bradley P, McMahon MJ. Diagnostic peritoneal lavage in acute pancreatitis the value of microscopy of the lavage fluid. Br J Surg 1981; 68: 245-6.

49 Ranson JHC, Pasternack BS. Statistical methods for quantifying the severity of clinical acute pancreatitis. J Surg Res 1977; 22: 79-91.

50 Osborne DH, Imrie CW, Carter DC. Biliary surgery in the same admission for gallstone-associated acute pancreatitis. Br J Surg 1981; 68: 758-61.

51 Ranson JHC. The timing of biliary surgery in acute pancreatitis. Ann Surg 1979; 189: $654-63$.

52 De Bolla AR, Obeid ML. Mortality in acute pancreatitis. Ann R Coll Surg Engl 1984; 66: $184-6$.

53 Mayer AD, McMahon MJ. Gallstones and acute pancreatitis - is the association underestimated? Br J Surg 1984. (In press)

54 Paloyan D, Simonowitz D, Skinner DB. The timing of biliary tract operations in patients with pancreatitis associated with gallstones. Surg Gynecol Obstet 1975; 141: 737-9.

55 Graham DF, Wylie FJ. Prediction of gall-stone pancreatitis by computer. Br Med J 1979; 1: $515-7$.

56 Glazer G, Murphy F, Clayden GS, Lawrence RG, Craig O. Radionuclide biliary scanning in acute pancreatitis. Br J Surg 1981; 68: 766-70.

57 McKay AJ, Imrie CW, O'Neill J, Duncan JG. Is an early ultrasound scan of value in acute pancreatitis? Br J Surg 1982; 69: 369-72.

58 McMahon MJ, Pickford IR. Biochemical prediction of gallstones early in an attack of acute pancreatitis. Lancet 1979; 2: 541-3.

59 Dammann HG, Döpner M, Wichert PV, Harders H, Hornborstel H. Gallstones and acute pancreatitis. Lancet 1980; 1: 308.

60 Neoptolemos JP, Hall AW, Finlay DF, Berry JM, Carr-Locke DL, Fossard DP. The urgent diagnosis of gallstones in acute pancreatitis: a prospective study of three methods. Br J Surg 1984; 71: 230-3.

61 Gossum A Van, Seferian V, Rodzynek JJ, Wettendorff P, Cremer M, Delcourt A. Early detection of biliary pancreatitis. Dig Dis Sci 1984; 29: 97-101.

62 Acosta JM, Rossi R, Ledesma CL. The usefulness of stool screening for diagnosing cholelithiasis in acute pancreatitis. A description of the technique. Am J Dig Dis 1977; 22: $168-72$.

63 MRC Multicentre Trial. Morbidity of acute pancreatitis: the effect of aprotinin and glucagon. Gut 1980; 21: 334-9.

64 Stone HH, Fabian TC. Peritoneal dialysis in the treatment of acute alcoholic pancreatitis. Surg Gynecol Obstet 1980; 150: 878-82.

65 Kivilaasko E, Lempinen M, Mäkeläinen A, Nikki P, Schröder T. Pancreatic resection versus peritoneal lavation for acute fulminant pancreatitis. A randomized prospective study. Ann Surg 1984; 199: 426-31.

66 Watts GT. Total pancreatectomy for fulminant pancreatitis. Lancet 1963; 2: 384.

67 Norton L, Eiseman B. Near total pancreatectomy for hemorrhagic pancreatitis. Am J Surg 1974; 127: 191-5.

68 Edelmann G, Boutelier PH. Le traitement des pancréatites aigues nécrosantes par l'ablation chirurgicale précoce des portions nécrosées. Chirurgie 1974; 100: 155-67.

69 Acosta JM, Rossi R, Galli OMR, Pellegrini CA, Skinner DB. Early surgery for acute gallstone pancreatitis: evaluation of a systematic approach. Surgery 1978; 83: 367-70.

70 Stone HH, Fabian TC, Dunlop WE. Gallstone pancreatitis. Biliary tract pathology in relation to time of operation. Ann Surg 1981; 194: 305-12.

71 McCutcheon AD. A fresh approach to the pathogenesis of pancreatitis. Gut 1968; 9: 296-310.

72 Tondelli P, Stutz K, Harder F, Schuppisser J-P, Allgöwer M. Acute gallstone pancreatitis: best timing for biliary surgery. Br J Surg 1982; 69: 709-10.

73 Mayer AD, McMahon MJ, Benson EA, Axon ATR. Operations upon the biliary tract in patients with acute pancreatitis: aims, indications and timing. Ann R Coll Surg Engl 1984; 
66: $179-83$.

74 Safrany L, Cotton PB. A preliminary report: Urgent duodenoscopic sphincterotomy for acute gallstone pancreatitis. Surgery 1981; 89: 424-8.

75 Spuy $\mathrm{S}$ van der. Endoscopic sphincterotomy in the management of gallstone pancreatitis. Endoscopy 1981; 13: 25-6.

76 Rosseland AR, Solhaug JH. Early or delayed endoscopic papillotomy (EPT) in gallstone pancreatitis. Ann Surg 1984; 199: 165-7. 